\title{
Quality Control Techniques and Related Factors for Hydroponic Leafy Vegetables
}

\author{
Jinghua Guo ${ }^{1}$ \\ Institute of Economic Crops, Hebei Academy of Agricultural and Forestry \\ Sciences, Shijiazhuang, 050031, China
}

Yan Yan'

The Institute of Vegetables and Flowers, Chinese Academy of Agricultural Sciences, Beijing 100081, China

Lingdi Dong ${ }^{2}$ and Yonggang Jiao

Institute of Economic Crops, Hebei Academy of Agricultural and Forestry Sciences, Shijiazhuang, 050031, China

Haizheng Xiong ${ }^{2}$

Department of Horticulture, University of Arkansas, Fayetteville, AR 72701

Linqi Shi, Yu Tian, and Yubo Yang

Institute of Economic Crops, Hebei Academy of Agricultural and Forestry Sciences, Shijiazhuang, 050031, China

\section{Ainong Shi \\ Department of Horticulture, University of Arkansas, Fayetteville, AR 72701}

Additional index words. lettuce, oilseed rape, supplementary light, fertilization, nutritional value

Abstract. Hydroponics has been an increasingly important field of vegetable production. However, a big issue with hydroponics is that certain crops can quickly accumulate high levels of nitrate-N $\left(\mathrm{NO}_{3} \pm-\mathrm{N}\right)$ from the hydroponic system. The objective of this research was to decrease $\mathrm{NO}_{3}$ accumulation and increase the nutritional value and yield of vegetable crops using lettuce and oilseed rape as a model under hydroponic production. In this study, two technologies were applied to leafy vegetable production: 1) using supplementary lighting (blue-violet diode) by manipulating illumination and 2) removing fertilization before harvest for a short term ( 3 or 5 days), thus providing a practical experiment for improving yield and edible qualities of hydroponic leaf vegetable production. Illumination was applied 4 hours a day (0500-0700 HR and 1700-1900 HR) during good weather, or 12 hours a day during bad weather with insufficient natural light $(<2000$ lux) during the autumn and winter seasons. Results showed that the lettuce cultivar Ou-Luo and the oilseed rape cultivar Ao-Guan Pakchoi had increased yield $\left(50.0 \%\right.$ and $88.3 \%$, respectively), decreased $\mathrm{NO}_{3}$ content $(26.3 \%$ and $30.8 \%$, respectively), and increased total soluble solids $(24.1 \%$ and $30.6 \%$, respectively). The 5-day fertilizer-free treatment before harvest resulted in $19.2 \%, 6.4 \%$, and $16.5 \%$ yield increases; and $26.0 \%, 24.3 \%$, and $47.8 \% \mathrm{NO}_{3}$ decreases in oilseed rape cultivar AoGuan Pakchoi and lettuce cultivars Da-Su-Sheng and Ou-Luo, respectively.

Hydroponics is an increasingly important field for counterseason vegetable production because of its efficiency in fertilization, water, and space use. Furthermore, it can overcome the disadvantages of soil culture, such as continuous cropping obstacles, diseases, and pests (Sardare and Admane, 2013). According to the market research report by Transparency Market Research (2018), the global hydroponics market is anticipated to reach a value of US\$12.1 billion by the end of 2015 from US\$6.9 billion in 2016 (Mordor

Received for publication 31 Dec. 2018. Accepted for publication $11 \mathrm{Feb} .2019$.

${ }^{2}$ Corresponding authors. E-mail: donglingdi@ 163.com or heixiazi2006@gmail.com. fertilizer is a big issue with hydroponic vegetable production (Colla et al., 2010). Human uptake of $\mathrm{NO}_{3}$ is mainly derived from the consumption of raw vegetables $(80 \%)$ and may be detrimental to one's health (Rathod et al., 2016). $\mathrm{NO}_{3}$ itself is relatively harmless, because the fatal adult dose is considered to be $\approx 100$-fold greater than the acceptable daily intake of $\mathrm{NO}_{3-}$ set by the European Union. Contrary to the relatively nondeleterious effect of the nitrate ion, when nitrite accumulates in the human body to a certain extent, it can form a strong carcinogennitrosamine - which may lead to carcinogenesis of the digestive system (Mensinga et al., 2003). The direct contribution of vegetables, fruits, and herbs to nitrite intake is relatively low (Riens and Heldt, 1992); however, the reduction of $\mathrm{NO}_{3}$ to nitrite is ubiquitous in the organism when it was mediated by the endogenous: about $5 \%$ of the $\mathrm{NO}_{3}$ is converted to nitrite after being ingested (Santamaria, 2006). Therefore, the accumulation of $\mathrm{NO}_{3}$ was considered to be a crucial factor in reducing the edible qualities of some vegetables. The $\mathrm{NO}_{3}$ content in leafy vegetables is related mainly to species and varieties, followed by environmental factors (e.g., light, soil, and moisture) and management (e.g., water, fertilization, and harvest) (Colla et al., 2018; Santamaria, 2006).

Minimizing $\mathrm{NO}_{3}$ levels and increasing nutritional value, such as soluble sugar and vitamin $\mathrm{C}$ content, in plants has never failed to fascinate researchers (Resh, 2016). Finding out some specific means of regulating the weight of substances in plants would improve their edible qualities dramatically (Anjana and Iqbal, 2007; Cavaiuolo and Ferrante, 2014). Nowadays, artificial environment management is a hot spot of agronomic system research (Jones, 2016). The relationship between light intensity and $\mathrm{NO}_{3}$ accumulation in vegetables has been reported in several types of research. $\mathrm{NO}_{3}$ accumulation in vegetables varies with season and tends to be stimulated during autumn and winter, with lower intensities than in spring (Santamaria et al., 1999). Human-made illumination has been widely applied in facility agriculture to compensate for insufficient natural lighting - especially during foggy, hazy autumns and winters - by extending time and enhancing intensity (Feng Tian, 2016). With the progress of artificial lighting, especially light-emitting diodes (LEDs) (Takemiya et al., 2005), illumination technologies in the hydroponic vegetable industry are being used more widely, which increases the yield and nutritional value of products significantly (Li and Zhou, 2013). Nitrogen (N) fertilization is the primary source of $\mathrm{NO}_{3}$ for edible crops (Donner and Kucharik, 2003). Usually, application of high-level nitrogenous fertilizer results in an increase in $\mathrm{NO}_{3}$ content in plants (Donner and Kucharik, 2003). Excessive applications of $\mathrm{NO}_{3}$ in fertilizers during the late stages of vegetative growth have more impact on $\mathrm{NO}_{3}$ accumulation in leafy vegetables than when applied during early stages because requirements for $\mathrm{N}$ 
decrease as plants mature (Blom-Zandstra and Lampe, 1983). For this reason, fertilization management during preharvest is an effective way to reduce $\mathrm{NO}_{3}$ accumulation and increase nutritional value without loss in yield (Borgognone et al., 2016; Malagoli et al., 2004).

In hydroponic crops, relative research on manipulating light and fertilization has increased significantly, and systematical studies have provided integrated and elaborate information to enlighten and guide hydroponic production (Colla et al., 2018). However, most studies were conducted in a laboratory or at a small scale, lacking reports of researching experiments were carried out on real and large-scale production conditions, because of the limit in labor, time, and facilities (Craker and Seibert, 1983; Kitaya et al., 1998; Li and Kubota, 2009; Rajapakse and Shahak, 2008).

Therefore, in our study, we implemented operability improvement on the management technologies of lighting and preharvest fertilization in the actual production process of commercial greenhouses to obtain practical and feasible measures for controlling the accumulation of $\mathrm{NO}_{3}$ and total soluble solids in hydroponic vegetables. We used lettuce (Lactuca sativa L.) and oilseed rape (Brassica napus L.) as model species in the research, which are the most commonly grown hydro- ponic leafy vegetables in North American and East Asia, respectively (Fitt et al., 2006; Resh, 2016). The objective of our research was to decrease $\mathrm{NO}_{3}$ accumulation and increase vitamin $\mathrm{C}$ and soluble sugar content, without losing yield in vegetable crops, by manipulating lighting and using two short-term ( $3 \mathrm{~d}$ or 5 d) fertilization breaks before harvest. About 18,480 lettuce and 5280 oilseed rape plants (including controls) were involved in our study, thus providing a theoretical basis for improving the qualities of hydroponic leaf vegetables in a practical case.

\section{Materials and Methods}

One oilseed rape cultivar, Ao-Guan Pakchoi; and two lettuce cultivars, American Da-Su-Sheng and Ou-Luo were used as examples of leaf vegetable crops in our study (Fig. 1A). The nutrient film technique (NFT) was applied to the experiments as hydroponic technology. The seedlings of the three cultivars were planted in the cultivation tank using the intensive plug-seeding method (Han, 2016), and the nutrient solution was circulated and flowed on the bottom of the container so the root system could absorb nutrients and water continuously, with a sufficient oxygen supply.

The experiments were conducted in the greenhouse of Hebei Academy of Agriculture and Forestry Sciences, Shijiazhuang, China, using a randomized complete block design. Two seeds were planted in each well of the 72-well (hole) trays and contained cottonseed waste:meteorite at 2:1 (v/v). After $25 \mathrm{~d}$, the uniform seedlings were selected and transplanted to a horizontal shelf in the NFT hydroponics system. The nutrient solution $\left[\mathrm{Ca}\left(\mathrm{NO}_{3}\right)_{2}\right.$. $4 \mathrm{H}_{2} \mathrm{O}, 600.00 \mathrm{mg} \cdot \mathrm{L}^{-1} ; \mathrm{KH}_{2} \mathrm{PO}_{4}, 180.00 \mathrm{mg} \cdot \mathrm{L}^{-1}$; $\mathrm{KNO}_{3}, 436.32 \mathrm{mg} \cdot \mathrm{L}^{-1} ; \mathrm{MgSO}_{4} \cdot 7 \mathrm{H}_{2} \mathrm{O}, 900.00$ $\mathrm{mg} \cdot \mathrm{L}^{-1}$; Fe-ethylenediaminetetraacetic acid, $23.00 \mathrm{mg} \cdot \mathrm{L}^{-1} ; \mathrm{NaNO}_{3}, 5.0 \mathrm{mg} \cdot \mathrm{L}^{-1} ; \mathrm{H}_{3} \mathrm{BO}_{3}$, $3.5 \mathrm{mg} \cdot \mathrm{L}^{-1} ; \mathrm{Na}_{2} \mathrm{MoO}_{4}, 0.24 \mathrm{mg} \cdot \mathrm{L}^{-1} ; \mathrm{ZnSO}_{4}$. $7 \mathrm{H}_{2} \mathrm{O}, 0.66 \mathrm{mg} \cdot \mathrm{L}^{-1} ; \mathrm{MnSO}_{4} \cdot 4 \mathrm{H}_{2} \mathrm{O}, 2.01 \mathrm{mg} \cdot \mathrm{L}^{-1}$; and $\mathrm{NaCl}, 0.88 \mathrm{mg} \cdot \mathrm{L}^{-1}$ ) was set to run for $60 \mathrm{~min}$ with a 40-min break in each cycle using a Siemens Smart Line computer system (Siemens, Beijing, China). The electrical conductivity of the nutrient solution was limited to 1.5 to $3.0 \mathrm{mS} \cdot \mathrm{cm}^{-1}$ and was measured using a conductivity meter (SX731; Sanxin, Shanghai, China). Each section of NFT hydroponics had 220 cells, and each cell contained four plants for lettuce and two plants for oilseed rape. After $30 \mathrm{~d}$, all the plants were harvested for yield detection. Thirty-three cells $(15 \%)$ were selected randomly from each section and were measured for their growth and edible qualities with three replications. In this way, a total of 396 plants ( 33 cells $\times 4$ plants $\times 3$ repeats $)$ and 198 plants for oilseed rape $(33$ cells $\times 2$

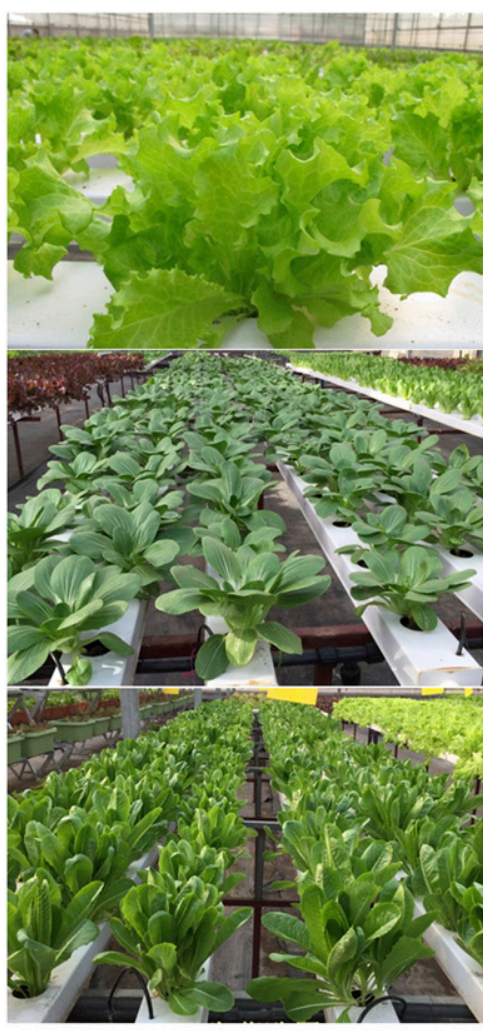

A

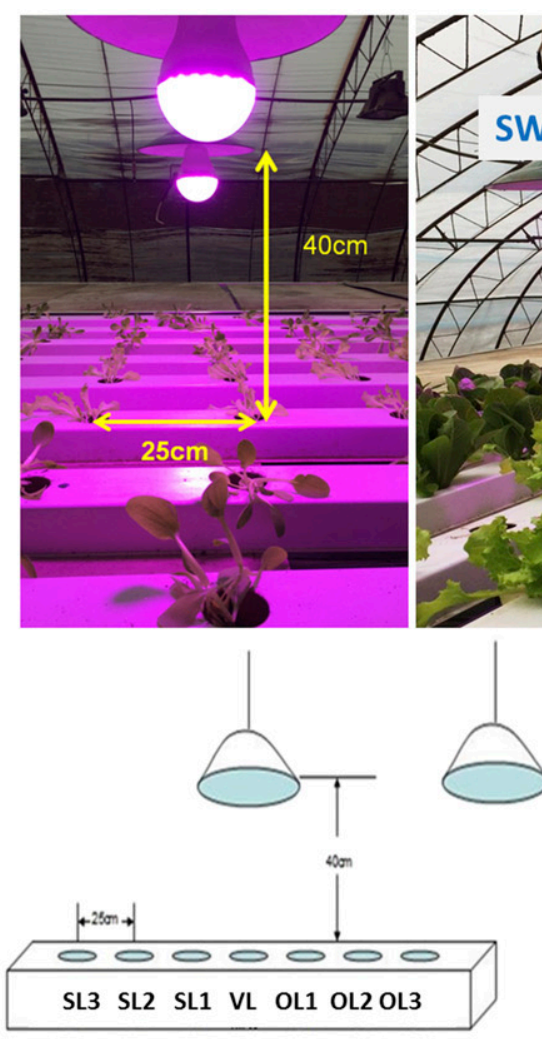

B

Fig. 1. (A) The varieties of leafy greens used in the experiment (from top to bottom): lettuce of Da-Su-Sheng, oilseed rape of Ao-Guan Pakchoi, and lettuce of Ou-Luo. (B) The plants and light-emitting diode (LED) arrangements. SL3, single light $75 \mathrm{~cm}$ from the vertical light (VL) hole; SL2, single light $50 \mathrm{~cm}$ from the VL hole; SL1, single light $25 \mathrm{~cm}$ from the VL hole; OL1, overlapping light at $25 \mathrm{~cm}$ from the VL hole; OL2, overlapping light at $50 \mathrm{~cm}$ from the VL hole; OL3, overlapping light at $75 \mathrm{~cm}$ from the VL hole. (C) Light intensities in different positions. SW, southwest; NW, northwest; SE, southeast; SW, southwest. 
Table 1. Light intensities and increases at different positions under four lamps.

\begin{tabular}{|c|c|c|c|c|c|c|c|c|}
\hline \multirow[b]{2}{*}{ Treatment } & \multicolumn{2}{|c|}{ Southwest lamp } & \multicolumn{2}{|c|}{ Southeast lamp } & \multicolumn{2}{|c|}{ Northwest lamp } & \multicolumn{2}{|c|}{ Northeast lamp } \\
\hline & Light (lux) & Increment (lux) & Light & Increment & Light & Increment & Light & Increment \\
\hline$\overline{\text { SL3 }}$ & $1,806.2 \mathrm{e}^{\mathrm{z}}$ & 305.29 & $1,824.87 \mathrm{e}$ & 323.95 & $1,264.50 \mathrm{~d}$ & 26.99 & $1,233.17 \mathrm{e}$ & -4.34 \\
\hline SL2 & $2,038.39 \mathrm{e}$ & 537.48 & $1,994.82 \mathrm{de}$ & 493.91 & $1,551.19 \mathrm{c}$ & 313.68 & $1,472.22 \mathrm{~cd}$ & 234.71 \\
\hline SL1 & $2,710.85 \mathrm{c}$ & $1,209.93$ & $2,543.42 \mathrm{c}$ & $1,042.51$ & $2,260.01 \mathrm{~b}$ & $1,022.50$ & $2,090.54 \mathrm{~b}$ & 853.03 \\
\hline VL & $3,491.23 \mathrm{a}$ & $1,990.32$ & $3,022.15 \mathrm{a}$ & $1,521.23$ & $2,827.79 \mathrm{a}$ & $1,590.28$ & $2,726.60 \mathrm{a}$ & $1,489.09$ \\
\hline OL1 & $3,079.15 \mathrm{~b}$ & $1,578.24$ & $2,762.78 \mathrm{~b}$ & $1,261.86$ & $2,247.26 \mathrm{~b}$ & $1,009.75$ & $2,287.36 \mathrm{~b}$ & $1,049.85$ \\
\hline OL2 & $2,278.92 \mathrm{~d}$ & 778.00 & $2,119.70 \mathrm{~d}$ & 618.78 & $1,583.03 \mathrm{c}$ & 345.52 & $1,648.08 \mathrm{c}$ & 410.57 \\
\hline OL3 & $1,909.69 \mathrm{e}$ & 408.77 & $1,838.45 \mathrm{e}$ & 337.53 & $1,279.00 \mathrm{~d}$ & 41.49 & $1,311.06 \mathrm{de}$ & 73.55 \\
\hline Control & $1,500.92 \mathrm{f}$ & - & $1,500.92 \mathrm{f}$ & - & $1,237.51 \mathrm{~d}$ & - & $1,237.51 \mathrm{e}$ & - \\
\hline
\end{tabular}

${ }^{\mathrm{z}}$ Lowercase letters represent statistical significance at $P=0.05$ for each parameter listed in the table.

SL3 = single light $75 \mathrm{~cm}$ from the vertical light (VL) hole; SL2 = single light $50 \mathrm{~cm}$ from the VL hole; SL1 = single light $25 \mathrm{~cm}$ from the VL hole; OL1 = overlapping light at $25 \mathrm{~cm}$ from the VL hole; OL2 = overlapping light at $50 \mathrm{~cm}$ from the VL hole; OL3 = overlapping light at $75 \mathrm{~cm}$ from the VL hole.

plants $\times 3$ repeats) were tested for each treatment.

The bluish violet (370-480 nm) LEDs (LX1330B; Sampo, Shanghai, China) were arranged evenly above the hydroponic shelves, with 18 hydroponic cells per LED on average. When daytime natural lighting was more than 2000 lux, the LEDs were turned on from 0500 to $0700 \mathrm{HR}$ each morning and from 1700 to $1900 \mathrm{HR}$ in the evening $(4 \mathrm{~h} /$ d). When daytime natural lighting was less than 2000 lux, the LEDs were turned on all day (0500-1900 HR). Light intensities were detected every hour at different positions under four LEDs: southwest, northwest, southeast, and northeast, as shown in Fig. 1B. The position of the LEDs and hydroponic cells have three lighting modes: single lighting (SL), vertical lighting (VL), and overlapping lighting (OL). Details of the illumination model from left to right in Fig. 1B are as follows: SL3, single light 75 $\mathrm{cm}$ from the vertical light (VL) hole; SL2, single light $50 \mathrm{~cm}$ from the VL hole; SL1, single light $25 \mathrm{~cm}$ from the VL hole; VL hole $40 \mathrm{~cm}$ below the LED perpendicularly; OL1, overlapping light at $25 \mathrm{~cm}$ from the VL hole; OL2, overlapping light at $50 \mathrm{~cm}$ from the VL hole; OL3, overlapping light at $75 \mathrm{~cm}$ from the VL hole.

After $30 \mathrm{~d}$ of growing, the growth traits and edible qualities of hydroponic vegetables were recorded to compare with the control groups, which were grown without illumination. Two durations ( $3 \mathrm{~d}$ and $5 \mathrm{~d}$ ) of fertilization break were applied before vegetable harvest. The nutrient solution was replaced with water to cut all nutrient supplies. After harvest, growth traits and edible qualities were estimated for each treatment.

The growth traits included plant height, amount of chlorophyll, plant weight, yield, leaf length and width (supplementary light treatment only), and root volume (for fertilizationbreak treatments). Edible quality traits included the amount of $\mathrm{NO}_{3}$, soluble sugar, vitamin C, and a total soluble solids (Beckles, 2012). Chlorophyll content was determined using a chlorophyll meter (SPAD-502; Generule, Shanghai, China (Ling et al., 2011), $\mathrm{NO}_{3}$ (Green et al., 1982) and the soluble sugar contents (Davies et al., 1998) were determined using a spectrophotometer (SP-1900 ultraviolet; Spectrum, Shanghai, China), vitamin $\mathrm{C}$ was determined by 2,6-dichlorophenol indophenol titration, and soluble solid content was determined using a sugar meter (PAL-1; Atago, Shenzhen, China). All the monitoring and controlling of environmental conditions, including temperature, humidity, light, oxygen, and $\mathrm{pH}$, were recorded automatically by a computer system (Siemens Smart Line).

Analysis of variance was performed using the general linear model of JMP Genomics 7. Student's $t$ test at $\alpha=0.05$ was used for multiple comparisons of the least square mean among the genotypes. The correlation coefficient for the traits was calculated using JMP Genomics 7 software.

\section{Result}

Supplementary lighting treatment and light intensities of different cells. As shown in Fig. 1B, under the four LEDs, the cell (hole) in the vertical light got the highest intensity, reached 1990.32 lux without natural light. Those cells farther away from the lights experienced gradually decreasing light intensity, and the value for each point is shown in Fig. 1C and Table 1. All light intensities for each cell in the illumination group were greater than the control.

Supplementary lighting impact on growth traits. To evaluate the lighting impact on growth and development of hydroponic vegetables, we evaluated the following growth traits: plant height, chlorophyll amount, leaf length, leaf width, fresh weight, and yield (Table 2). Plant height, chlorophyll amount, leaf width, and fresh weight of illuminated 'Ou-Luo' were greater than the controls, especially for the plants in VL cells, which had a $50.0 \%$ increase in yield. These values declined with a decrease in light intensity. Similar impacts were also found in 'Ao-Guan Pakchoi'. Plant height with supplemental lighting was significantly greater than the control. The best yield was $7751.7 \mathrm{~kg} /$ acre in VL cells, which was an $88.31 \%$ increase over the control. The gradient changes in growth traits in both lettuce and oilseed rape revealed that proper illumination could promote the growth and development of leafy vegetables.

Supplementary lighting impact on edible qualities. Under lighting conditions, 'Ou-Luo' displayed considerable variation in all nutrition traits compared to the control (Table 3).
$\mathrm{NO}_{3}$ content deceased by $26.30 \%$; total soluble solids and sugar contents increased as much as $24.05 \%$ and $33.5 \%$, respectively; and vitamin $\mathrm{C}$ showed a gradual decline with light intensity increase. The $\mathrm{NO}_{3}$ content in 'Ao-Guan Pakchoi' with supplemental lighting was reduced as much as $30.76 \%$ than plants with insufficient lighting. Total soluble solids and sugar contents increased by $30.6 \%$ and $30.5 \%$, respectively; but vitamin $\mathrm{C}$ content decreased under supplemental lighting.

After being subjected to lighting treatments, the accumulation of $\mathrm{NO}_{3}$ in lettuce correlated negatively with soluble sugar content and total soluble solids $(r=-0.699$ and $r=$ -0.787 , respectively); a positive correlation between $\mathrm{NO}_{3}$ content and vitamin $\mathrm{C}$ content was seen $(r=0.788)$ (Table 4$)$. The same phenomena were also seen in oilseed rape: $\mathrm{NO}_{3}$ content correlated negatively with total soluble solids and soluble sugar content $(r=$ -0.956 and $r=-0.813$, respectively); and a positive correlation between $\mathrm{NO}_{3}$ and vitamin $\mathrm{C}$ content was seen $(r=0.741)$ (Table 4$)$. These results indicate that lighting treatments can decrease $\mathrm{NO}_{3}$ content and simultaneously increase total soluble solids and soluble sugar contents, but not vitamin $\mathrm{C}$ content.

Fertilization-break impact on growth traits. In our study, "fertilization break" was defined as cutting off all nutrient supply in the short term. The nutrient solution in the hydroponic system was replaced by pure water $3 \mathrm{~d}$ or $5 \mathrm{~d}$ before harvest. As shown in Table 5, the growth traits of 'Ao-Guan Pakchoi' with the fertilization break were greater than the control, especially plant height, chlorophyll amount, root volume, and plant weight. The two treatments ( $3 \mathrm{~d}$ and $5 \mathrm{~d}$ ) improved yield by $10.7 \%$ and $19.2 \%$, respectively.

Moreover, the growth traits of the 5-d treatment were slightly greater than the 3-d treatment. In 'Ou-Luo', the amount of chlorophyll, root volume, and plant weight increased significantly. Moreover, yield increased by $11.9 \%$ and $16.5 \%$, respectively, with the 3-d and 5-d treatments. However, for 'Da-Su-Sheng', there was no significant difference between the control and the treatments in almost all traits. There was only a $2.0 \%$ and $6.4 \%$ increase in plant weight. These results confirm that a short-term fertilization break does not reduce plant 
Table 2. Growth traits under different lighting treatments.

\begin{tabular}{|c|c|c|c|c|c|c|c|c|c|}
\hline Treatment & $\mathrm{Ht}(\mathrm{cm})$ & $\begin{array}{c}\text { Chlorophyll } \\
(\%)\end{array}$ & $\begin{array}{c}\text { Leaf } \\
\text { length }(\mathrm{cm})\end{array}$ & $\begin{array}{c}\text { Leaf } \\
\text { width }(\mathrm{cm})\end{array}$ & $\begin{array}{c}\text { Fresh } \\
\text { wt }(\mathrm{kg})\end{array}$ & Yield (kg/acre) & $\begin{array}{l}\text { Yield increase } \\
(\%)\end{array}$ & Vegetable & Cultivar \\
\hline$\overline{\text { SL3 }}$ & $16.6 \mathrm{bc}^{\mathrm{z}}$ & $41 \mathrm{~b}$ & $13.9 \mathrm{c}$ & $8.4 \mathrm{a}$ & $0.11 \mathrm{a}$ & $5,880.6 \mathrm{e}$ & 10.00 & Lettuce & Ou-Luo \\
\hline SL2 & $15.95 \mathrm{bc}$ & $43.3 \mathrm{ab}$ & $15.3 \mathrm{abc}$ & $8.35 \mathrm{a}$ & $0.12 \mathrm{a}$ & $6,415.2 \mathrm{~d}$ & 20.00 & & \\
\hline SL1 & $17.35 \mathrm{~b}$ & $46.1 \mathrm{a}$ & $15.75 \mathrm{abc}$ & $7.9 \mathrm{a}$ & $0.125 \mathrm{a}$ & $6,682.5 \mathrm{c}$ & 25.00 & & \\
\hline VL & $19.4 \mathrm{a}$ & $33.3 \mathrm{~d}$ & $17.4 \mathrm{a}$ & $8.5 \mathrm{a}$ & $0.15 \mathrm{a}$ & $8,019 \mathrm{a}$ & 50.00 & & \\
\hline OL1 & $17.2 \mathrm{~b}$ & $36.95 \mathrm{c}$ & $15.15 \mathrm{bc}$ & $9.15 \mathrm{a}$ & $0.14 \mathrm{a}$ & $7,484.4 \mathrm{~b}$ & 40.00 & & \\
\hline OL2 & $17.3 \mathrm{~b}$ & $35.45 \mathrm{~cd}$ & $16.9 \mathrm{ab}$ & $8.9 \mathrm{a}$ & $0.125 \mathrm{a}$ & $6,682.5 \mathrm{c}$ & 25.00 & & \\
\hline OL3 & $17.35 \mathrm{~b}$ & $42.8 \mathrm{~b}$ & $15.3 \mathrm{abc}$ & $8.8 \mathrm{a}$ & $0.105 \mathrm{a}$ & $5,613.3 \mathrm{f}$ & 5.00 & & \\
\hline Control & $15.267 \mathrm{c}$ & $35.7 \mathrm{~cd}$ & $15.8 \mathrm{abc}$ & $7.733 \mathrm{a}$ & $0.1 \mathrm{a}$ & $5,346 \mathrm{~g}$ & - & & \\
\hline SL3 & $14.2 \mathrm{e}$ & $41.6 \mathrm{a}$ & $9.8 \mathrm{~b}$ & 6.5 & $0.1 \mathrm{a}$ & $5,078.7 \mathrm{e}$ & 23.38 & Oilseed rape & Ao-Guan Pakchoi \\
\hline SL2 & $15.4 \mathrm{de}$ & $38.25 \mathrm{~d}$ & $10.4 \mathrm{ab}$ & 6.65 & $0.11 \mathrm{a}$ & $5,880.6 \mathrm{~d}$ & 42.86 & & \\
\hline SL1 & $18.6 \mathrm{a}$ & $40.45 \mathrm{~b}$ & $10.95 \mathrm{a}$ & 6.85 & $0.12 \mathrm{a}$ & $6,147.9 \mathrm{c}$ & 49.35 & & \\
\hline VL & $16.4 \mathrm{bcd}$ & $36.8 \mathrm{e}$ & $10.25 \mathrm{ab}$ & 6.75 & $0.15 \mathrm{a}$ & $7,751.7 \mathrm{a}$ & 88.31 & & \\
\hline OL1 & $15.95 \mathrm{~cd}$ & $39.45 \mathrm{c}$ & $9.75 \mathrm{~b}$ & 6.45 & $0.13 \mathrm{a}$ & $6,682.5 b$ & 62.34 & & \\
\hline OL2 & $17.8 \mathrm{ab}$ & $40.8 \mathrm{ab}$ & $10.1 \mathrm{ab}$ & 6.2 & $0.12 \mathrm{a}$ & $6,147.9 \mathrm{c}$ & 49.35 & & \\
\hline OL3 & $17.2 \mathrm{abc}$ & $34.85 \mathrm{f}$ & $9.95 \mathrm{ab}$ & 6.65 & $0.11 \mathrm{a}$ & $5,880.6 \mathrm{~d}$ & 42.86 & & \\
\hline Control & $11.83 \mathrm{f}$ & $37.33 \mathrm{de}$ & $10.63 \mathrm{ab}$ & 6.6 & $0.08 \mathrm{a}$ & $4,116.42 \mathrm{f}$ & - & & \\
\hline
\end{tabular}

${ }_{\mathrm{z}}$ Lowercase letters represent statistical significance at $P=0.05$ for each parameter listed in the table.

SL3 = single light $75 \mathrm{~cm}$ from the vertical light (VL) hole; SL2 = single light $50 \mathrm{~cm}$ from the VL hole; SL1 = single light $25 \mathrm{~cm}$ from the VL hole; OL1 = overlapping light at $25 \mathrm{~cm}$ from the VL hole; OL2 = overlapping light at $50 \mathrm{~cm}$ from the VL hole; OL $3=$ overlapping light at $75 \mathrm{~cm}$ from the VL hole.

Table 3. Edible qualities in different lights.

\begin{tabular}{|c|c|c|c|c|c|c|c|c|c|c|}
\hline Treatment & $\begin{array}{c}\text { Nitrate } \\
\left(\mathrm{mg} \cdot \mathrm{kg}^{-1}\right)\end{array}$ & Decrease $(\%)$ & $\begin{array}{c}\text { Soluble } \\
\text { Solid (\%) }\end{array}$ & Increase $(\%)$ & $\begin{array}{c}\text { Vitamin C } \\
\left(\mathrm{mg} \cdot 100 \mathrm{~g}^{-1}\right)\end{array}$ & Increase $(\%)$ & $\begin{array}{c}\text { Soluble } \\
\text { sugar }\left(\mathrm{mg}^{\prime} \mathrm{g}^{-1}\right)\end{array}$ & Increase $(\%)$ & Vegetable & Cultivar \\
\hline$\overline{\text { SL3 }}$ & $2,718.65 \mathrm{a}^{\mathrm{z}}$ & 4.45 & $4.25 \mathrm{bc}$ & 7.59 & $2.07 \mathrm{bc}$ & -37.27 & $13.43 \mathrm{bcd}$ & 12.2 & Lettuce & Ou-Luo \\
\hline SL2 & $2,443.43 \mathrm{~b}$ & 11 & $4.35 \mathrm{bc}$ & 10.13 & $2.49 \mathrm{~b}$ & -24.55 & $12.16 \mathrm{~cd}$ & 1.59 & & \\
\hline SL1 & $2,367.45 \mathrm{~b}$ & 13.77 & $4.25 \mathrm{bc}$ & 7.59 & $1.89 \mathrm{c}$ & -42.73 & $13.87 \mathrm{bc}$ & 15.87 & & \\
\hline VL & $2,023.52 \mathrm{~d}$ & 26.3 & $4.9 \mathrm{a}$ & 24.05 & $1.68 \mathrm{c}$ & -49.09 & $15.98 \mathrm{a}$ & 33.5 & & \\
\hline OL1 & $2,107.91 \mathrm{~cd}$ & 23.22 & $4.8 \mathrm{ab}$ & 21.52 & $1.78 \mathrm{c}$ & -46.06 & $14.31 \mathrm{~b}$ & 19.55 & & \\
\hline OL2 & $2,097.37 \mathrm{~cd}$ & 23.61 & $4.3 \mathrm{bc}$ & 8.86 & $1.98 \mathrm{c}$ & -40 & $13.34 \mathrm{bcd}$ & 11.45 & & \\
\hline OL3 & $2,311.63 \mathrm{bc}$ & 15.8 & $4.7 \mathrm{ab}$ & 18.99 & $2.08 \mathrm{bc}$ & -36.97 & $14.88 \mathrm{ab}$ & 24.31 & & \\
\hline Control & $2,845.5 \mathrm{a}$ & - & $3.95 \mathrm{c}$ & - & $3.3 \mathrm{a}$ & - & $11.97 \mathrm{~d}$ & - & & \\
\hline SL3 & $2,381 \mathrm{~b}$ & 20.21 & $3.7 \mathrm{a}$ & 15.63 & $30.56 \mathrm{~d}$ & -27.24 & $6.3 \mathrm{bc}$ & 3.28 & Oilseed rape & Ao-Guan \\
\hline SL2 & $2,162.9 \mathrm{~cd}$ & 27.52 & $3.8 \mathrm{a}$ & 18.75 & $32.23 \mathrm{~cd}$ & -23.26 & $6.99 \mathrm{abc}$ & 14.59 & & Pakchoi \\
\hline SL1 & $2,132.5 \mathrm{~cd}$ & 28.53 & $4.05 \mathrm{a}$ & 26.56 & $32.71 \mathrm{c}$ & -22.12 & $7.47 \mathrm{ab}$ & 22.46 & & \\
\hline VL & $2,066 \mathrm{~d}$ & 30.76 & $4.18 \mathrm{a}$ & 30.63 & $36.52 \mathrm{~b}$ & -13.05 & $7.96 \mathrm{a}$ & 30.49 & & \\
\hline OL1 & $2,111.6 \mathrm{~cd}$ & 29.23 & $4.1 \mathrm{a}$ & 28.13 & $31.66 \mathrm{~cd}$ & -24.62 & $7.95 \mathrm{a}$ & 30.33 & & \\
\hline OL2 & $2,141.7 \mathrm{~cd}$ & 28.23 & $3.96 \mathrm{a}$ & 23.75 & $32.77 \mathrm{c}$ & -21.98 & $7.21 \mathrm{abc}$ & 18.20 & & \\
\hline OL3 & $2,218.5 \mathrm{c}$ & 25.65 & $3.87 \mathrm{a}$ & 20.94 & $33.25 \mathrm{c}$ & -20.83 & $7.46 \mathrm{ab}$ & 22.30 & & \\
\hline Control & $2,984 \mathrm{a}$ & - & $3.2 \mathrm{~b}$ & - & $42 \mathrm{a}$ & - & $6.1 \mathrm{c}$ & - & & \\
\hline
\end{tabular}

${ }^{\mathrm{z}}$ Lowercase letters represent statistical significance at $P=0.05$ for each parameter listed in the table.

SL3 = single light $75 \mathrm{~cm}$ from the vertical light (VL) hole; SL2 = single light $50 \mathrm{~cm}$ from the VL hole; SL1 = single light $25 \mathrm{~cm}$ from the VL hole; OL1 = overlapping light at $25 \mathrm{~cm}$ from the VL hole; OL2 = overlapping light at $50 \mathrm{~cm}$ from the VL hole; OL3 = overlapping light at $75 \mathrm{~cm}$ from the VL hole.

development or yield, but may increase them instead.

Fertilization-break impact on edible qualities. The results in Table 6 reveal that during the 3-d and 5-d treatments, the $\mathrm{NO}_{3}$ content of 'Ao-Guan Pakchoi' decreased by $20.9 \%$ and $26.0 \%$, respectively; followed by vitamin $\mathrm{C}$ content decrease of $19.9 \%$ and $19.6 \%$, respectively; a total soluble solids content decrease of $2.6 \%$ and $8.7 \%$, respectively; and soluble sugar decreased by $0.7 \%$ and $3.9 \%$, respectively, compared with the control. The decreased $\mathrm{NO}_{3}$ content was detected in 'American Da-Su-Sheng' (15.9\% and $47.8 \%$ ). The fertilization break also improved other edible qualities of 'American Da-Su-Sheng', especially during the 5-d treatment. The soluble sugar content increased by $54.0 \%$, vitamin C content increased by $82.8 \%$, and the total soluble solid content increased by $27.9 \%$. We also noticed the 5-d treatment in 'Ou-Luo' improved edible qualities as well. The $\mathrm{NO}_{3}$ content was reduced by $24.3 \%$, the soluble sugar content increased by $88.6 \%$, vitamin C content increased by $16.7 \%$, and total soluble solid content increased by $20 \%$. These result indicate that a fertilization break decreased the $\mathrm{NO}_{3}$ content and, at the same time, increased total soluble solids, soluble sugar, and vitamin $\mathrm{C}$ contents, especially during the 5-d treatment for the two lettuce cultivars, but not for oilseed rape.

During the fertilization break, the $\mathrm{NO}_{3}$ content in 'Ao-Guan Pakchoi' correlated positively with vitamin $\mathrm{C}$, total soluble solids, and soluble sugar contents $(r=0.980,0.846$, and 0.769 , respectively) (Table 7). This means the treatment reduced the $\mathrm{NO}_{3}$ content and other edible qualities synchronously in similar degrees. Contrary results were observed in lettuce; $\mathrm{NO}_{3}$ correlated negatively with soluble sugar, vitamin $\mathrm{C}$, and total soluble solids contents $(r=-0.943,-0.981$, and -0.975 , respectively for 'American Da-SuSheng'; and $r=-0.977,-0.930$, and -0.858 for 'Ou-Luo', respectively). The fertilization break increased soluble sugar, vitamin $\mathrm{C}$ and total soluble solids contents while reducing $\mathrm{NO}_{3}$, especially in the 5 -d treat- ment. In addition, there were no negative influences on yield.

\section{Discussion}

Growth traits and edible qualities. In our study, we describe $\mathrm{NO}_{3}$ content and total soluble solids (vitamin $\mathrm{C}$ and soluble sugar) as "edible qualities" to evaluate vegetable toxins and nutrition. It is worth noting that total soluble solids is a general term for all soluble substances (Kader, 2002). Because of limitations in labor and cost, we measured only two of them-vitamin $\mathrm{C}$ and soluble sugar-individually. Total soluble solids in our study is regarded as an index equaling vitamin $\mathrm{C}$ and soluble sugar used assess nutritional value.

For two management strategies (supplementary light and fertilization), the growth traits we selected in the experiments were somewhat different. Often, insufficient lighting stimulates petiole development and elongation, which make leaves growing lengthwise; on the contrary, leaves elongate 
Table 4. Correlations of nitrate, vitamin C, soluble sugar, and total soluble solid contents under light supplementation.

\begin{tabular}{|c|c|c|c|c|c|c|c|}
\hline & Pearson & Nitrate & Vitamin C & Soluble sugar & Soluble solid & Vegetable & Cultivar \\
\hline \multirow[t]{2}{*}{ Nitrate } & $r$ & 1 & 0.788 & -0.699 & -0.787 & Lettuce & Ou-Luo \\
\hline & $P$ & & 0.02 & 0.054 & 0.02 & & \\
\hline \multirow[t]{2}{*}{ Vitamin C } & $r$ & 0.788 & 1 & -0.789 & -0.731 & & \\
\hline & $P$ & 0.02 & & 0.02 & 0.039 & & \\
\hline \multirow[t]{2}{*}{ Soluble sugar } & $r$ & -0.699 & -0.789 & 1 & 0.859 & & \\
\hline & $P$ & 0.054 & 0.02 & & 0.006 & & \\
\hline \multirow[t]{2}{*}{ Soluble solid } & $r$ & -0.787 & -0.731 & 0.859 & 1 & & \\
\hline & $P$ & 0.02 & 0.039 & 0.006 & & & \\
\hline \multirow[t]{2}{*}{ Nitrate } & $r$ & 1 & 0.741 & -0.813 & -0.956 & Oilseed rape & Ao-Guan Pakchoi \\
\hline & $P$ & & 0.036 & 0.014 & 0 & & \\
\hline \multirow[t]{2}{*}{ Vitamin C } & $r$ & 0.741 & 1 & -0.323 & -00.597 & & \\
\hline & $P$ & 0.036 & & 0.436 & 0.118 & & \\
\hline \multirow[t]{2}{*}{ Soluble sugar } & $r$ & -0.813 & -0.323 & 1 & 0.908 & & \\
\hline & $P$ & 0.014 & 0.436 & & 0.002 & & \\
\hline \multirow[t]{2}{*}{ Soluble solid } & $r$ & -0.956 & -0.597 & 0.908 & 1 & & \\
\hline & $P$ & 0 & 0.118 & 0.002 & & & \\
\hline
\end{tabular}

$r=$ correlation coefficient; $P=P$-value.

Table 5. Growth traits in different fertilization-break treatments.

\begin{tabular}{|c|c|c|c|c|c|c|c|c|c|c|c|}
\hline Treatment & $\mathrm{Ht}(\mathrm{cm})$ & $\begin{array}{c}\text { Chlorophyll } \\
(\%)\end{array}$ & $\begin{array}{l}\text { Aboveground } \\
\text { fresh wt }(\mathrm{g})\end{array}$ & $\begin{array}{l}\text { Below- ground } \\
\text { fresh wt }(\mathrm{g})\end{array}$ & $\begin{array}{c}\text { Root } \\
\text { volume } \\
(\mathrm{mL})\end{array}$ & $\begin{array}{l}\text { Aboveground } \\
\text { dry wt (g) }\end{array}$ & $\begin{array}{l}\text { Below- ground } \\
\text { dry wt (g) }\end{array}$ & $\begin{array}{c}\text { Yield } \\
\text { (kg/acre) }\end{array}$ & $\begin{array}{c}\text { Yield } \\
\text { increase } \\
(\%)\end{array}$ & Vegetable & Cultivar \\
\hline Control & $21.44 \mathrm{a}^{\mathrm{z}}$ & $43.81 \mathrm{~b}$ & $90 \mathrm{c}$ & $60.12 \mathrm{~b}$ & $16.5 \mathrm{c}$ & $6.39 \mathrm{a}$ & $3.13 \mathrm{~b}$ & $7,878.86 \mathrm{c}$ & - & Oilseed & Ao-Guan \\
\hline $3 \mathrm{~d}$ & $22.74 \mathrm{a}$ & $45.06 \mathrm{ab}$ & $100 \mathrm{~b}$ & $60.83 \mathrm{~b}$ & $17.62 \mathrm{~b}$ & $6.92 \mathrm{a}$ & $3.19 \mathrm{ab}$ & $8,724.59 \mathrm{~b}$ & 10.73 & rape & Pakchoi \\
\hline $5 \mathrm{~d}$ & $23.58 \mathrm{a}$ & $47.3 \mathrm{a}$ & $110 \mathrm{a}$ & $70.0 \mathrm{a}$ & $20.31 \mathrm{a}$ & $7.16 \mathrm{a}$ & $4.08 \mathrm{a}$ & $9,392.29 \mathrm{a}$ & 19.21 & & \\
\hline Control & $30.04 \mathrm{ab}$ & $16.46 \mathrm{a}$ & $125.45 \mathrm{~b}$ & $18.3 \mathrm{~b}$ & $18.2 \mathrm{a}$ & $3.51 \mathrm{~b}$ & $2.95 \mathrm{~b}$ & $7,684.878 \mathrm{c}$ & - & Lettuce & American \\
\hline $3 d$ & $31.36 \mathrm{a}$ & $16.58 \mathrm{a}$ & $126.09 \mathrm{ab}$ & $20.51 \mathrm{ab}$ & $20.2 \mathrm{a}$ & $3.81 \mathrm{a}$ & $4.74 \mathrm{a}$ & $7,837.236 \mathrm{~b}$ & 1.98 & & Da-Su-Sheng \\
\hline $5 \mathrm{~d}$ & $29.7 \mathrm{~b}$ & $15.3 \mathrm{a}$ & $131.16 \mathrm{a}$ & $21.73 \mathrm{a}$ & $20.6 \mathrm{a}$ & $3.92 \mathrm{a}$ & $4.87 \mathrm{a}$ & $8,173.487$ a & 6.35 & & \\
\hline Control & $25.52 \mathrm{a}$ & $34.04 \mathrm{ab}$ & $96.53 \mathrm{c}$ & $15.61 \mathrm{~b}$ & $13.8 \mathrm{c}$ & $2.53 \mathrm{~b}$ & $1.64 \mathrm{~b}$ & $5,994.99 \mathrm{c}$ & - & & Ou-Luo \\
\hline $3 \mathrm{~d}$ & $27.58 \mathrm{a}$ & $38.14 \mathrm{a}$ & $105.02 \mathrm{~b}$ & $20.44 \mathrm{a}$ & $20.4 \mathrm{a}$ & $3.18 \mathrm{a}$ & $4.3 \mathrm{a}$ & $6,707.1 \mathrm{~b}$ & 11.87 & & \\
\hline $5 \mathrm{~d}$ & $27.7 \mathrm{a}$ & $32.86 \mathrm{~b}$ & $111.47 \mathrm{a}$ & $19.14 \mathrm{a}$ & $17.6 \mathrm{~b}$ & $3.46 \mathrm{a}$ & $3.23 \mathrm{a}$ & $6,982.36 \mathrm{a}$ & 16.47 & & \\
\hline
\end{tabular}

${ }^{\mathrm{z}}$ Lowercase letters represent statistical significance at $P=0.05$ for each parameter listed in the table.

Table 6. The edible qualities in different fertilization-break treatments.

\begin{tabular}{|c|c|c|c|c|c|c|c|c|c|c|}
\hline Treatment & $\begin{array}{c}\text { Nitrate } \\
\left(\mathrm{mg} \cdot \mathrm{kg}^{-1}\right)\end{array}$ & Decrease $(\%)$ & $\begin{array}{c}\text { Vitamin C } \\
\left(\mathrm{mg} \cdot 100 \mathrm{~g}^{-1}\right)\end{array}$ & Increase $(\%)$ & $\begin{array}{l}\text { Soluble } \\
\text { solid (\%) }\end{array}$ & Increase (\%) & $\begin{array}{c}\text { Soluble } \\
\text { sugar }\left(\mathrm{mg} \cdot \mathrm{g}^{-1}\right)\end{array}$ & Increase $(\%)$ & Vegetable & Cultivar \\
\hline Control & $3,739.42 \mathrm{a}^{z}$ & & $62.77 \mathrm{a}$ & & $5.75 \mathrm{a}$ & & $4.36 \mathrm{a}$ & & Oilseed rape & Ao-Guan Pakchoi \\
\hline $3 \mathrm{~d}$ & $2,958.54 \mathrm{~b}$ & 20.88 & $50.3 \mathrm{~b}$ & -19.87 & $5.6 \mathrm{a}$ & -2.61 & $4.33 \mathrm{a}$ & -0.69 & & \\
\hline $5 \mathrm{~d}$ & $2,765.9 \mathrm{~b}$ & 26.03 & $50.49 \mathrm{~b}$ & -19.56 & $5.25 \mathrm{a}$ & -8.70 & $4.19 \mathrm{a}$ & -03.90 & & \\
\hline Control & $3,271.32 \mathrm{a}$ & & $0.58 \mathrm{~b}$ & & $3.05 \mathrm{c}$ & & $1.88 \mathrm{~b}$ & & Lettuce & American \\
\hline $3 \mathrm{~d}$ & $2,752.56 \mathrm{~b}$ & 15.86 & $0.65 \mathrm{~b}$ & 12.07 & $3.5 \mathrm{~b}$ & 14.75 & $1.871 \mathrm{~b}$ & -0.48 & & Da-Su-Sheng \\
\hline $5 \mathrm{~d}$ & $1,709.21 \mathrm{c}$ & 47.75 & $1.06 \mathrm{a}$ & 82.76 & $3.9 \mathrm{a}$ & 27.87 & $2.913 \mathrm{a}$ & 54.95 & & \\
\hline Control & $2,590.83 \mathrm{a}$ & & $1.14 \mathrm{a}$ & & $3.25 \mathrm{c}$ & & $2.488 \mathrm{c}$ & & & Ou-Luo \\
\hline $3 \mathrm{~d}$ & $2,569.78 \mathrm{a}$ & 0.81 & $1.04 \mathrm{a}$ & -8.77 & $3.6 \mathrm{~b}$ & 10.77 & $3.047 \mathrm{~b}$ & 22.47 & & \\
\hline $5 \mathrm{~d}$ & $1,961.66 \mathrm{~b}$ & 24.28 & $1.33 \mathrm{a}$ & 16.67 & $3.9 \mathrm{a}$ & 20.00 & $4.692 \mathrm{a}$ & 88.59 & & \\
\hline
\end{tabular}

${ }^{\mathrm{z}}$ Lowercase letters represent statistical significance at $P=0.05$ for each parameter listed in the table.

sideways under adequate light (Muramoto et al., 1965; Pepper et al., 1994; van der Graaff et al., 2000). It has been reported that the shortage of nutrients in hydroponic solution could stimulate root development (Hodge et al., 2009; Trejo-Téllez and Gómez-Merino, 2012). Therefore, in our study, we tested leaf growth and root features of the plants to verify the effects of lighting and fertilization breaks. We found that leaf and root features are in accordance with growth in insufficient lighting and fertilization-free conditions. These two representative morphology changes can help researchers ensure rationality of the results quickly. We also measured chlorophyll content to evaluate the health of the plants, because abundant chlorophyll usually implies vigorous growth and development of plants (Chaerle and Van Der Straeten, 2001).
Supplementary lighting. Light is one of the most critical factors during plant growth. Despite photosynthesis, most plant characteristics are also influenced by the mode of light, including intensity, rhythm, period, and type (Kami et al., 2010; Takemiya et al., 2005). There are many theories which can explain the correlation between light and $\mathrm{NO}_{3}$ content, and the lighting drove activity changes of $\mathrm{NO}_{3}$ reductase can be one of the causes (Konstantopoulou et al., 2010). As others have reported, a reduction in light intensity is accompanied by a decrease in $\mathrm{NO}_{3}$ reductase activity, which induces fast $\mathrm{NO}_{3}$ accumulation in several important leafy vegetables (Fallovo et al., 2009; Pilgrim et al., 1993). Our research confirmed toxicity reduction with gradients in light intensity. Another explanation of $\mathrm{NO}_{3}$ reduction in our experiment is the variation of $\mathrm{NO}_{3}$ among different parts of every plant. The order of
$\mathrm{NO}_{3}$ content has been listed by former researches as petiole $>$ leaf $>$ stem $>$ root $>$ inflorescence $>$ tuber $>$ bulb $>$ fruit $>$ seed (Santamaria et al., 1999). In general, the $\mathrm{NO}_{3}$ concentration in the petiole is about two to five times greater than in leaf, depending on the vegetable species (Elia et al., 2000; Koh et al., 2012; Umar et al., 2007). During the development of the plant, the petiole is the basic part to form the leaf, root, and other storage organs, where $\mathrm{NO}_{3}$ tends to accumulate, compared with other parts of the vegetable (Maynard et al., 1976; Santamaria et al., 1999). The greater growth of the petiole under insufficient lighting was recognized in our study, although it was not surprising to find high-level $\mathrm{NO}_{3}$ accumulation in these plants.

Despite our encouraging results, we found some discrepancies with other work. With supplemental lighting, vitamin $\mathrm{C}$ decreased 
Table 7. Correlation of nitrate, vitamin C, soluble sugar, and total soluble solid contents after nutrient break.

\begin{tabular}{|c|c|c|c|c|c|c|c|}
\hline & Pearson & Nitrate & Soluble sugar & Vitamin C & Soluble solid & Vegetable & Cultivar \\
\hline \multirow[t]{2}{*}{ Nitrate } & $r$ & 1 & -0.943 & -0.981 & -0.975 & Lettuce & American Da-Su-Sheng \\
\hline & $P$ & & 0.216 & 0.125 & 0.144 & & \\
\hline \multirow[t]{2}{*}{ Soluble sugar } & $r$ & -0.943 & 1 & 0.99 & 0.845 & & \\
\hline & $P$ & 0.216 & & 0.091 & 0.36 & & \\
\hline \multirow[t]{2}{*}{ Vitamin C } & $r$ & -0.981 & 0.99 & 1 & 0.912 & & \\
\hline & $P$ & 0.125 & 0.091 & & 0.269 & & \\
\hline \multirow[t]{2}{*}{ Soluble solid } & $r$ & -0.975 & 0.845 & 0.912 & 1 & & \\
\hline & $P$ & 0.144 & 0.36 & 0.269 & & & \\
\hline \multirow[t]{2}{*}{ Nitrate } & $r$ & 1 & -0.977 & -0.93 & -0.858 & Lettuce & Ou-Luo \\
\hline & $P$ & & 0.138 & 0.239 & 0.343 & & \\
\hline \multirow[t]{2}{*}{ Soluble sugar } & $r$ & -0.977 & 1 & 0.829 & 0.949 & & \\
\hline & $P$ & 0.138 & & 0.377 & 0.205 & & \\
\hline \multirow[t]{2}{*}{ Vitamin C } & $r$ & -0.93 & 0.829 & 1 & 0.61 & & \\
\hline & $P$ & 0.239 & 0.377 & & 0.582 & & \\
\hline \multirow[t]{2}{*}{ Soluble solid } & $r$ & -0.858 & 0.949 & 0.61 & 1 & & \\
\hline & $P$ & 0.343 & 0.205 & 0.582 & & & \\
\hline \multirow[t]{2}{*}{ Nitrate } & $r$ & 1 & 0.769 & 0.980 & 0.846 & Oilseed rape & Ao-Guan Pakchoi \\
\hline & $P$ & & 0.441 & 0.128 & 0.358 & & \\
\hline \multirow[t]{2}{*}{ Soluble sugar } & $r$ & 0.769 & 1 & 0.626 & 0.991 & & \\
\hline & $P$ & 0.441 & & 0.569 & 0.083 & & \\
\hline \multirow[t]{2}{*}{ Vitamin C } & $r$ & 0.980 & 0.626 & 1 & 0.722 & & \\
\hline & $P$ & 0.128 & 0.569 & & 0.486 & & \\
\hline \multirow[t]{2}{*}{ Soluble solid } & $r$ & 0.846 & 0.991 & 0.722 & 1 & & \\
\hline & $P$ & 0.358 & 0.083 & 0.486 & & & \\
\hline
\end{tabular}

slightly with increasing light intensity, which does not reflect results from previous studies (Li and Kubota, 2009). Those studies claimed that, with a rapid increase in biomass under supplemental lighting, vitamin $\mathrm{C}$ should increase synchronously with the growth surge (Sørensen et al., 1994). This phenomenon may be caused by inconsistent $\mathrm{NO}_{3}$ accumulation and vitamin $\mathrm{C}$ production during the whole growth period, which is affected easily by many factors (Chen et al., 2003; Lee and Kader, 2000).

Fertilization break. $\mathrm{N}$ is the necessary element during plant growth and development, but it is also the source of the $\mathrm{NO}_{3}$ hazard (Mantelin and Touraine, 2004). An appropriate nutrient formula and management would minimize this harm without losses in yield or nutritional value (BarYosef et al., 2009). Short-term fertilization break has been considered to be a reliable method for reducing the $\mathrm{NO}_{3}$ hazard (Borgognone et al., 2016). Our results showed that the yield of all tested plants increased, and $\mathrm{NO}_{3}$ contents declined, after the fertilization break treatment, which is consistent with the reports. As plants reach maturity, their requirements for $\mathrm{N}$ decrease (BlomZandstra and Lampe, 1983). Because the fertilization break removed all excess $\mathrm{N}$ supplies, plants demonstrated a dramatically reduced $\mathrm{NO}_{3}$ content (Borgognone et al., 2016; Malagoli et al., 2004). In another aspect, the absence of fertilization could stimulate root development, which could consume a large amount of $\mathrm{NO}_{3}$ stores in petioles. Because $\mathrm{N}$ mainly helps to form storage organs (roots, rhizomes, and tubers) (Alexander et al., 2008), the edible part (yield) of the vegetable would not be influenced by the treatments. The mechanism by which yield increased during the two fertilization-break treatments is still not clear yet.
Moreover, contrary to the lettuce cultivars used in our study, total soluble solids, soluble sugar, and vitamin $\mathrm{C}$ contents decreased with $\mathrm{NO}_{3}$ decline in oilseed rape as reported by $\mathrm{Oh}$ et al. (2009). Although this result can be explained by content variations among species, according to Bell (1993), further research is still needed to elucidate why fertilizer-break treatment reduced the $\mathrm{NO}_{3}$ content but increased yield, especially for those regional preference vegetables like oilseed rape.

Impacts and outlooks. Hydroponic systems have been used as one of the essential modes for facility agriculture in commercial production for several crops (TrejoTéllez and Gómez-Merino, 2012). An ideal system must construct and manage all the facilities in an appropriate way to gain the expected profit (Jones, 2016). Considering the enormous input, a sustainable strategy including economy, health, and environmental friendliness are required for all facility agriculture systems (Zhang et al., 2015). Our research followed this strategy in three aspects: 1) enhanced the edible qualities and decreased toxicity in vegetables, 2) improved the vegetable yield in natural-light shortage seasons, and 3) reduced waste emission into the environment by our lighting and fertilization-break treatments. Moreover, opposed to laboratory or small-scale production, we mobilized considerable resources in facilities, labor, technology, and policies to support this research, which resulted in more than 23,000 experimental plants harvested for yield. Meanwhile, $15 \%$ of them were collected to assess growth traits and edible qualities. More important, hydroponic systems may boost the vegetable industry in developing countries where air and soil pollution causes one-third a reduction in value of autumn and winter vegetable pro- duction in the greenhouse (Fallovo et al., 2009; Jackson et al., 2004).

Few studies compare with ours in terms of scale. However, we have to admit there were some weaknesses in our study. First, because of device and technique limitations, we had to use lux to measure the light intensity, which is preferred for evaluating intensity in humans over plants. Second, because of labor and technique limitations, we could only detect $\mathrm{NO}_{3}$, total soluble solids, vitamin $\mathrm{C}$, and soluble sugar to evaluate edible qualities, which are not comprehensive vegetable qualities (Shewfelt and Bruckner, 2000). Third, with such a large scale of vegetable production, we could not make sure equipment, facilities, and labor worked the same during the growth period, which may cause relatively large errors compared with laboratory experiments. For example, the measurement and recording of light intensities were conducted manually by different technicians who used hand-held detectors, all of which could be prone to errors. In the future, we will endeavor to improve the rigor and consistency of our experiments.

During long-term evolution, natural selection, and cultivation, the crop like lettuce and oilseed rape was "gaining" more and more redundancy genes that induce a lot of differences in plant behaviors, even under a same circumstance among species and varieties (Allard and Bradshaw, 1964; Burns et al., 2011). Therefore, regarding improvement in lighting and fertilization management for leafy vegetables, it is necessary to consider the mode of treatment, such as continuous or noncontinuous, short term or long term, and so on. The combination of several treatments also needs to be studied in future research, which may also influence the metabolic balance in plants (Mooney, 1972). Thus, it is possible, by changing the balance of 
endogenous synthesis, especially in vivo substances, to control the development of plants (Li et al., 2017). Also, the impacts of lighting and fertilization break on the qualities and yield of other vegetables need further experimentation, which is warranted to assess the physiologic and molecular changes linked to these modifications and to identify treatments that can be applied strategically to reduce $\mathrm{NO}_{3}$ accumulation in leafy vegetables.

\section{Literature Cited}

Alexander, J., D. Benford, A. Cockburn, J. Cravedi, E. Dogliotti, A. Di Domenico, M. FernandezCruz, J. Fink-Gremmels, P. Fürst, and C. Galli. 2008. Opinion of the Scientific Panel on Contaminants in the Food Chain on a request from the European Commission to perform a scientific risk assessment on nitrate in vegetables. EFSA J. 689:1-79.

Allard, R.W. and A.D. Bradshaw. 1964. Implications of genotype-environmental interactions in applied plant breeding 1. Crop Sci. 4:503-508.

Anjana, S.U. and M. Iqbal. 2007. Nitrate accumulation in plants, factors affecting the process, and human health implications: A review. Agron. Sustain. Dev. 27:45-57.

Bar-Yosef, B., N. Mattson, and H. Lieth. 2009. Effects of NH4:NO3:urea ratio on cut roses yield, leaf nutrients content and proton efflux by roots in closed hydroponic system. Scientia Hort. 122:610-619.

Beckles, D.M. 2012. Factors affecting the postharvest total soluble solids and sugar content of tomato (Solanum lycopersicum L.) fruit. Postharvest Biol. Technol. 63:129-140.

Bell, J. 1993. Factors affecting the nutritional value of canola meal: A review. Can. J. Anim. Sci. 73:689-697.

Blom-Zandstra, G. and J.E. Lampe. 1983. The effect of chloride and sulphate salts on the nitrate content in lettuce plants (Lactuca sativa L.). J. Plant Nutr. 6:611-628.

Borgognone, D., Y. Rouphael, M. Cardarelli, L. Lucini, and G. Colla. 2016. Changes in biomass, mineral composition, and quality of cardoon in response to $\mathrm{NO}^{-}: \mathrm{Cl}^{-}$ratio and nitrate deprivation from the nutrient solution. Front. Plant Sci. 7:978.

Burns, I.G., K. Zhang, M.K. Turner, M. Meacham, K. Al-Redhiman, J. Lynn, M.R. Broadley, P. Hand, and D. Pink. 2011. Screening for genotype and environment effects on nitrate accumulation in 24 species of young lettuce. J. Sci. Food Agr. 91:553-562.

Cavaiuolo, M. and A. Ferrante. 2014. Nitrates and glucosinolates as strong determinants of the nutritional quality in Rocket leafy salads. $\mathrm{Nu}-$ trients 6:1519.

Chaerle, L. and D. Van Der Straeten. 2001. Seeing is believing: Imaging techniques to monitor plant health. Biochim. Biophys. Acta Gene Struct. Expression 1519:153-166.

Chen, Z., T.E. Young, J. Ling, S.-C. Chang, and D.R. Gallie. 2003. Increasing vitamin C content of plants through enhanced ascorbate recycling. Proc. Natl. Acad. Sci. USA 100:3525-3530.

Colla, G., H.-J. Kim, M.C. Kyriacou, and Y. Rouphael. 2018. Nitrate in fruits and vegetables. Scientia Hort. 237:221-238.

Colla, G., C.M.C. Suárez, M. Cardarelli, and Y. Rouphael. 2010. Improving nitrogen use efficiency in melon by grafting. HortScience 45:559-565.

Craker, L. and M. Seibert. 1983. Light and the development of Grand Rapids lettuce. Can. J. Plant Sci. 63:277-281.
Davies, D., R. Merry, A. Williams, E. Bakewell, D. Leemans, and J. Tweed. 1998. Proteolysis during ensilage of forages varying in soluble sugar content. J. Dairy Sci. 81:444-453.

Donner, S.D. and C.J. Kucharik. 2003. Evaluating the impacts of land management and climate variability on crop production and nitrate export across the Upper Mississippi Basin. Global Biogeochem. Cycles 17, doi:10.1029/ $2001 \mathrm{~GB} 001808$.

Elia, A., G. Conversa, and M. Gonnella. 2000. Dosi di azoto, produzione e accumulo di nitrati in lattuga allevata in idrocoltur. Acta Hort. 548:529-536, doi: 10.17660/ActaHortic. 2001. 548.64 .

Fallovo, C., Y. Rouphael, E. Rea, A. Battistelli, and G. Colla. 2009. Nutrient solution concentration and growing season affect yield and quality of Lactuca sativa $\mathrm{L}$. var. acephala in floating raft culture. J. Sci. Food Agr. 89:1682-1689.

Feng Tian. 2016. Study and optimization of lighting systems for plant growth in a controlled environment. Chemical and Process Engineering. Université Paul Sabatier - Toulouse III. English. NNT:2016TOU30248.

Fitt, B.D.L., H. Brun, M. Barbetti, and S. Rimmer 2006. World-wide importance of phoma stem canker (Leptosphaeria maculans and L. biglobosa) on oilseed rape (Brassica napus), p. 315. In: B.D.L. Fitt, N. Evans, B.J. Howlett, and B.M. Cooke (eds.). Sustainable strategies for managing Brassica napus (oilseed rape) resistance to Leptosphaeria maculans (phoma stem canker). Springer, Dordrecht, the Netherlands.

Green, L.C., D.A. Wagner, J. Glogowski, P.L. Skipper, J.S. Wishnok, and S.R. Tannenbaum. 1982. Analysis of nitrate, nitrite, and [15N] nitrate in biological fluids. Anal. Biochem. 126:131-138.

Han, L. 2016. Technological regulation for intensive plug seedling. China Agr. Knowledge 54-57.

Hodge, A., G. Berta, C. Doussan, F. Merchan, and M. Crespi. 2009. Plant root growth, architecture, and function. Plant Soil 321:153-187.

Jackson, L., I. Ramirez, R. Yokota, S. Fennimore, S. Koike, D. Henderson, W. Chaney, F. Calderón, and K. Klonsky. 2004. On-farm assessment of organic matter and tillage management on vegetable yield, soil, weeds, pests, and economics in California. Agr. Ecosyst. Environ. 103:443-463.

Jones, J.B., Jr. 1982. Hydroponics: Its history and use in plant nutrition studies. J. Plant Nutr. 5:1003-1030.

Jones, J.B., Jr. 2016. Hydroponics: A practical guide for the soilless grower. 2nd ed. CRC Press, Boca Raton, FL.

Kader, A.A. (ed.). 2002. Postharvest technology of horticultural crops, 3rd edition. University of California, Agriculture and Natural Resources, Publication 3311, 535 p.

Kami, C., S. Lorrain, P. Hornitschek, and C. Fankhauser. 2010. Light-regulated plant growth and development. Curr. Top. Dev. Biol. 91:2966.

Kitaya, Y., G. Niu, T. Kozai, and M. Ohashi. 1998. Photosynthetic photon flux, photoperiod, and $\mathrm{CO} 2$ concentration affect growth and morphology of lettuce plug transplants. HortScience 33:988-991.

Koh, E., S. Charoenprasert, and A.E. Mitchell. 2012. Effect of organic and conventional cropping systems on ascorbic acid, vitamin C, flavonoids, nitrate, and oxalate in 27 varieties of spinach (Spinacia oleracea L.). J. Agr. Food Chem. 60:3144-3150.
Konstantopoulou, E., G. Kapotis, G. Salachas, S.A. Petropoulos, I.C Karapanos, and H.C Passam. 2010. Nutritional quality of greenhouse lettuce at harvest and after storage in relation to $\mathrm{N}$ application and cultivation season. Scientia Hort. 125:93.e1-93.e5.

Li, M., S. Chen, F. Liu, L. Zhao, Q. Xue, H. Wang, M. Chen, P. Lei, D. Wen, and J.A. Sanchez-Molina. 2017. A risk management system for meteorological disasters of solar greenhouse vegetables. Precis. Agr. 18:9971010.

Lee, S.K. and A.A. Kader. 2000. Preharvest and postharvest factors influencing vitamin $\mathrm{C}$ content of horticultural crops. Postharvest Biol. Technol. 20:207-220.

Li, Q. and C. Kubota. 2009. Effects of supplemental light quality on growth and phytochemicals of baby leaf lettuce. Environ. Expt. Bot. 67:5964.

Li, L. and T. Zhou. 2013. Corporate social responsibility of haze weather. J. Appl. Sci. 13:4612.

Ling, Q., W. Huang, and P. Jarvis. 2011. Use of a SPAD-502 meter to measure leaf chlorophyll concentration in Arabidopsis thaliana. Photosynth. Res. 107:209-214.

Malagoli, P., P. Laine, E. Le Deunff, L. Rossato, B. Ney, and A. Ourry. 2004. Modeling nitrogen uptake in oilseed rape cv Capitol during a growth cycle using influx kinetics of root nitrate transport systems and field experimental data. Plant Physiol. 134:388400.

Mantelin, S. and B. Touraine. 2004. Plant growthpromoting bacteria and nitrate availability: Impacts on root development and nitrate uptake. J. Expt. Bot. 55:27-34.

Maynard, D.N., A.V. Barker, P.L. Minotti, and N.H. Peck. 1976. Nitrate accumulation in vegetables, p. 71-118. In: Advances in agronomy. Elsevier.

Mensinga, T.T., G.J. Speijers, and J. Meulenbelt. 2003. Health implications of exposure to environmental nitrogenous compounds. Toxicol. Rev. 22:41-51.

Mooney, H. 1972. The carbon balance of plants. Annu. Rev. Ecol. Syst. 3:315-346.

Mordor Intelligence. 2018. Hydroponics market: Growth, trends and forecasts (2019-2024). 6 June 2019. <https://www.mordorintelligence. com/industry-reports/hydroponics-market $>$.

Muramoto, H., J. Hesketh, and M. El-Sharkawy. 1965. Relationships among rate of leaf area development, photosynthetic rate, and rate of dry matter production among American cultivated cottons and other species 1 . Crop Sci. 5:163-166.

Oh, M.M., E.E. Carey, and C. Rajashekar. 2009. Environmental stresses induce health-promoting phytochemicals in lettuce. Plant Physiol. Biochem. 47:578-583.

Pepper, A., T. Delaney, T. Washburnt, D. Poole, and J. Chory. 1994. DET1, a negative regulator of light-mediated development and gene expression in Arabidopsis, encodes a novel nuclear-localized protein. Cell 78:109-116.

Pilgrim, M.L., T. Caspar, P.H. Quail, and C.R. McClung. 1993. Circadian and light-regulated expression of nitrate reductase in Arabidopsis. Plant Mol. Biol. 23:349-364.

Rajapakse, N.C. and Y. Shahak. 2008. Lightquality manipulation by horticulture industry: Annual plant reviews. Light Plant Dev. 30:290-307.

Rathod, K.S., S. Velmurugan, and A. Ahluwalia. 2016. A "green" diet-based approach to 
cardiovascular health? Is inorganic nitrate the answer? Mol. Nutr. Food Res. 60:185202.

Resh, H.M. 2016. Hydroponic food production: A definitive guidebook for the advanced home gardener and the commercial hydroponic grower. CRC Press, Boca Raton, FL.

Riens, B. and H.W. Heldt. 1992. Decrease of nitrate reductase activity in spinach leaves during a light-dark transition. Plant Physiol. 98:573-577.

Santamaria, P. 2006. Nitrate in vegetables: Toxicity, content, intake and EC regulation. J. Sci. Food Agr. 86:10-17.

Santamaria, P., A. Elia, F. Serio, and E. Todaro. 1999. A survey of nitrate and oxalate content in fresh vegetables. J. Sci. Food Agr. 79:18821888 .
Sardare, M.D. and S.V. Admane. 2013. A review on plant without soil-hydroponics. Intl. J. Res. Eng. Technol. 2:299-304.

Shewfelt, R.L. and B. Bruckner. 2000. Fruit and vegetable quality: An integrated view. CRC Press, Boca Raton, FL.

Sørensen, J.N., A. Johansen, and N. Poulsen. 1994. Influence of growth conditions on the value of crisphead lettuce. Plant Foods Hum. Nutr. 46:1-11.

Takemiya, A., S.-I. Inoue, M. Doi, T. Kinoshita, and K.-I. Shimazaki. 2005. Phototropins promote plant growth in response to blue light in low light environments. Plant Cell 17:1120-1127.

Transparency Market Research. 2018. Rising demand for soil-less agriculture to empower hydroponics market. 6 June 2019. <https:// www.transparencymarketresearch.com/article/ hydroponics-market.html>.
Trejo-Téllez, L.I and F.C . Gómez-Merino. 2012. Nutrient solutions for hydroponic systems, $\mathrm{p}$. 1-24. In: Toshiki Asao (ed.). Hydroponics: A standard methodology for plant biological researches. InTech, Rijeka, Croatia.

Umar, S., M. Iqbal, and Y. Abrol. 2007. Are nitrate concentrations in leafy vegetables within safe limits? Curr. Sci. 92:355-360.

van der Graaff, E., A. Dulk-Ras, P. Hooykaas, and B. Keller. 2000. Activation tagging of the LEAFY PETIOLE gene affects leaf petiole development in Arabidopsis thaliana. Development 127:4971-4980.

Zhang, Y., P. Wang, L. Wang, G. Sun, J. Zhao, H. Zhang, and N. Du. 2015. The influence of facility agriculture production on phthalate esters distribution in black soils of northeast China. Sci. Total Environ. 506:118-125. 